\title{
Biphallia in imposexed females of marine gastropods: new record for Nassarius vibex from Brazil
}

\author{
Cardoso, RS.*, Caetano, CHS. and Cabrini, TMB. \\ Laboratório de Ecologia Marinha \\ Universidade Federal do Estado do Rio de Janeiro - UNIRIO, \\ Av. Pasteur, 458, Urca, CEP 22290-240, Rio de Janeiro, RJ, Brazil \\ *e-mail: rcardoso@unirio.br
}

Received May 13, 2008 - Accepted May 28, 2008 - Distributed February 28, 2009

(With 1 figure)

Imposex is an endocrine disruption syndrome, in which females of marine gastropods develop sexual characteristics of males (penis and/or vas deferens) (Smith, 1971). This syndrome is caused by tributyltin (TBT) or triphenyltin (TPT), toxic organotin compounds found in naval paints used as antifouling system in boats and artificial structures (Gibbs and Bryan, 1987 and Axiak et al., 2003).

Quantification of TBT by chemical analysis in water or sediment is very onerous, therefore imposex as a tool to detect contamination by organotin compounds is often used. Five genus of marine gastropods in the Brazilian littoral have already been studied and the occurrence of imposex was related to either mild or severe contamination by TBT (Fernandez et al., 2005 and Limaverde et al., 2007). Nassarius (Mollusca: Gastropoda) is a ubiquitous genus that has been proposed as a bioindicator of TBT pollution (Marshall and Rajkumar, 2003). Here, we report the novel occurrence of imposex in Nassarius vibex (Say) in south Brazil and the biphallia in imposexed females of this species.

Specimens of $N$. vibex were collected at Flexeira beach $\left(22^{\circ} 56^{\prime} \mathrm{S}\right.$ and $\left.43^{\circ} 53^{\prime} \mathrm{W}\right)$, Itacuruçá Island, Rio de Janeiro state, Brazil, in the intertidal zone at spring low tide in September 2007. Two fixed transects $(500 \mathrm{~m}$ apart) were established from the lower limit of the swash zone to $10 \mathrm{~m}$ above the drift line (supralittoral). Next, ten equally spaced sampling strata parallel to the water line were marked according to a systematic design with stratification. At each stratum, five replicate quadrats of $0.04 \mathrm{~m}^{2}$ (systematically allocated $3 \mathrm{~m}$ apart) were taken to a depth of $25 \mathrm{~cm}$ and sieved through $0.7 \mathrm{~mm}$ mesh. This beach is exposed to effects of the yachting activities of Itacuruçá Yacht Club (distant $1.1 \mathrm{~km}$ ) and Sepetiba Harbor (distant $7.3 \mathrm{~km}$ ), which constituted potential sources of TBT pollution.

In the laboratory, shell length (Figure 1a and b) was measured with a vernier caliper, then cracked and opened in a vice, and the individuals of $N$. vibex removed and examined for sex determination. Individuals having seminal vesicle were identified as males while others with seminal vesicle absent, as females. Females with male sex organs (e.g. penis) were identified as imposexed females.
Penis length of males and imposexed females was measured under a stereoscopic microscope and the Relative Penis Length Index (RPLI) and Relative Penis Size Index (RPSI) were calculated according to Gibbs and Bryan (1987).

A total of 155 individuals were collected, with 86 males (55.48\%, Figure 1c) and 69 females (44.52\%). All the females examined present the occurrence of imposex (Figure 1d). Two imposexed females presented biphallia (i.e. double penis, see Figure 1e and f). These

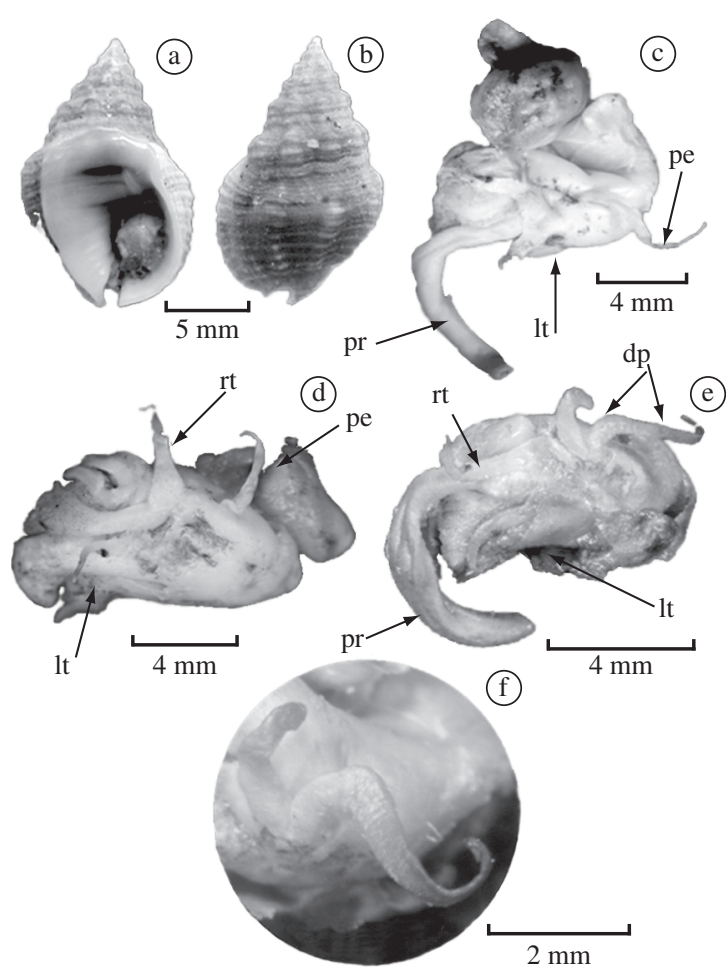

Figure 1. Nassarius vibex. a) and b) Shell; c) soft parts of an adult male; d) soft parts of an imposexed female; e) soft parts of an imposexed female with biphallia; and f) detail of the double penis. Abbreviations: dp, double penis; lt, left tentacle; pe, penis; pr, proboscis; rt, right tentacle. 
penises were similar in shape but have different lengths ( $+1=3.07 / 1.96 \mathrm{~mm}$ (shell length $12.87 \mathrm{~mm}$ ) and ${ }^{\circ} 2=$ 7.87 / $1.78 \mathrm{~mm}$ (shell length $12.89 \mathrm{~mm}$ )). The occurrence of biphallia is an additional abnormality of the female reproductive system and has recently been reported by Meirelles et al. (2007) for an imposexed female of the gastropod Leucozonia nassa (Gmelin) .

The penis length of females exhibiting imposex ranged from 0.27 to $9.26 \mathrm{~mm}$ while male penis length ranged from 3.85 to $11.21 \mathrm{~mm}$. Female penis length (mean $=3.07 \mathrm{~mm}, \mathrm{SD}= \pm 1.96$ ) was significantly smaller $(t$ test $=15.86 \mathrm{P}<0.05)$ than male penis length $($ mean $=$ $7.87 \mathrm{~mm}, \mathrm{SD}= \pm 1.78$ ). However, there was no significant difference between male mean shell length $(12.89 \mathrm{~mm})$ and that of females $(12.87 \mathrm{~mm})(t$ test $=1,65 \mathrm{P}>0.05)$. RPLI and RPSI values were 39.01 and $5.93 \%$, respectively. These values were higher when compared to those obtained by Lima-Verde et al. (2007) for the same species in northeast Brazil (RPLI $=0$ to 8.25 , RPSI $=0$ to 0.06), suggesting that Flexeira beach presented higher TBT contamination levels. Further studies will be conducted to assess the use of Nassarius vibex as a bioindicator species.

\section{References}

AXIAK, V., MICALLEF, D., MUSCAT, J., VELLA, A. and MINTO, B., 2003. Imposex as a biomonitoring tool for marine pollution by tributyltin: some further observations. Environmental International, vol. 28, no. 8, p. 743-749.

GIBBS, PE. and BRYAN, G., 1987. TBT paints and the demise of the dog-whelk, Nucella lapillus (Gastropoda). In Proceedings of Oceans '87: the ocean - an international workplace ; 28 Sept - 01 Oct, 1987; Halifax. Piscataway, New Jersey: IEEE Service Center, p. 1482-1487.

FERNANDEZ, MA., WAGENER, ALR., LIMAVERDE, AM., SCOFIELD, AL., PINHEIRO, FM. and RODRIGUES, E. 2005. Imposex and surface speciation: a combined approach in evaluating organotin contamination in Guanabara Bay, Rio de Janeiro, Brazil. Marine Environment Research, vol. 59, no. 5, p. $435-452$.

LIMAVERDE, AM., WAGENER, ALR., FERNANDEZ, MA. and SCOFIELD, A.L. 2007. Stramonita haemastoma as a bioindicator for organotin contamination in tropical coastal environments. Marine Environmental Research, vol. 64, no. 3, p. 384-398.

LIMAVERDE, FB., CASTRO, IB. and ROCHA-BARREIRA, CA., 2007. Monitoramento passivo do alcance da contaminação por compostos organoestânicos do rio Ceará, nordeste do Brasil, Brasil. In Proceedings of the XX Encontro Brasileiro de Malacologia, 5 Out- 10 Out, 2007. Rio de Janeiro: Universidade do Estado do Rio de Janeiro, p. 330.

MARSHALL, DJ. and RAJKUMAR, A., 2003. Imposex in the indigenous Nassarius kraussianus (Mollusca: Neogastropoda) from South African harbours. Marine Pollution Bulletin, vol. 46, no. 9 , p. $1150-1155$.

MEIRELLES, CAO., CASTRO, IB. and PINHEIRO, JCL., 2007. A first record of biphallia in imposexed female of Leucozonia nassa (Caenogastropoda: Fasciolariidae). Journal of the Marine Biological Association of the United Kingdom 2: Biodiversity Records, vol. 5424, p. 1-3.

SMITH, BS., 1971. Sexuality in the American mud-snail Nassarius obsoletus (Say, 1822). Proceedings of the Malacological Society of London, vol. 39, no. 5, p. 377-378. 